\title{
KARAKTERISTIK MEKANIK KOMPOSIT SERAT BAMBU KONTINYU DENGAN PERLAKUAN ALKALI
}

\author{
Sofyan Djamil dan Agustinus Purna Irawan \\ Staff Pengajar Program Studi Teknik Mesin Jurusan Teknik Mesin \\ Fakultas Teknik Universitas Tarumanagara Jakarta \\ e-mail: sofyand@ft.untar.ac.id
}

\begin{abstract}
Commonly used reinforcement materials are fibers, particles or flakes which have higher strength and modulus than matrix. Natural fibers of lignosellulose derived from natural resources such as bamboo, sisal, kenaf, hemp, wood and others are the largest raw materials found on earth, especially Indonesia. The reinforcement of natural fibers in composite materials has the advantage of good mechanical properties and is cheaper compared to synthetic fibers, using natural bamboo fiber, it can be made green composite. The research stages are bamboo raw material taken from the village of Pebasiran Parung Panjang BogorJawa Barat type bamboo apus (giganchtoloa apus), aged 3-4 years. Bamboo dried with surrounding air for 2 weeks, then cut with a knife manually, hinggga shaped-sized fiber; thickness 0.6 - $0.8 \mathrm{~mm}$ and width 6 - $8 \mathrm{~mm}$. The $5 \% \mathrm{NaOH}$ soaked fiber, for 72 hours, is dried at room temperature. Reinforcement using plain weave and twill weave type. Composite is made by hand lay up process, with thickness of 2 mm. Testing test is made with standard ASTM D3039 / D3039M-08, Observation of fiber structure with optical microscope. From research data and the calculation is then obtained for plain woven type before alkali treatment yield strength is $15.60 \pm 2.24 \mathrm{MPa}$, after alkali treatment yield strength is $18.80 \pm 2.13 \mathrm{MPa}$. For this type of woven twill before alkali treatment yield strength is $24.48 \pm$ 3.92 MPa, after alkali treatment yield strength is $29.90 \pm 2.27 \mathrm{MPa}$. For plain woven type before alkali treatment process the maximal tensile strength is $20.94 \pm 3.69 \mathrm{MPa}$, after alkali treatment process the maximal tensile strength is $25.53 \pm 3.94 \mathrm{MPa}$. For the type of woven twill before the alkali treatment the maximal tensile strength is $30.18 \pm 7.26 \mathrm{MPa}$, after alkali treatment the maximal tensile strength is 35.15 $\pm 2.81 \mathrm{MPa}$.For plain weave type before alkali treatment strain is $2.29 \pm 0.36 \%$, after alkali treatment strain is $2.47 \pm 0.25 \%$. For this type of woven twill before alkali treatment strain is $2.27 \pm 0.40 \%$, after alkali treatment strain is $2.27 \pm 0.40 \%$.
\end{abstract}

Keyword: fibers, alkali treatment, twill, plain

\section{PENDAHULUAN}

Komponen komposit terdiri penguat (reinforcement) yang berbentuk serat (fiber) yang mempunyai kekuatan dan kekakuan tinggi dan pengikat (matrix) yang berfungsi untuk menjaga posisi serat, mentransmisikan gaya geser, juga sebagai pelapis serat [1]. Matrik yang digunakan mempunyai kekuatan yang rendah tetapi ulet, dalam hal ini polimer, jenis resin epoxy yang mempunyai viskositas yang rendah, sehingga dalam proses manufaktur metode hand lay-up mudah digunakan. Serat sangat dominan untuk menentukan kekuatan dan kekakuan komposit, semakin kecil ukuran serat, akan meningkatkan kekuatan dan gaya adhesive [2]. Penggunaan serat alam bambu dalam rangka untuk mendapatkan material yang bersifat ramah lingkungan. Sifat mekanis komposit sangat dipengaruhi sudut orientasi serat, dalam hal ini jenis anyaman (woven), yang digunakan dalam pembuatan komposit [3].

\section{METODE PENELITIAN}

Metodologi ini dilakukan dengan beberapa tahapan: bahan baku, pembuatan helaian bambu secara manual, pembuatan spesimen dan pengujian menurut standard ASTM D3039/D3039M-12, analisis hasil pengujian, dan kesimpulan, seperti diagram alir pada Gambar 1.

\section{Diagram Alir Proses Penelitian}

Metode yang dilakukan dijelaskan dalam diagram alir (flowchart) di bawah ini: 


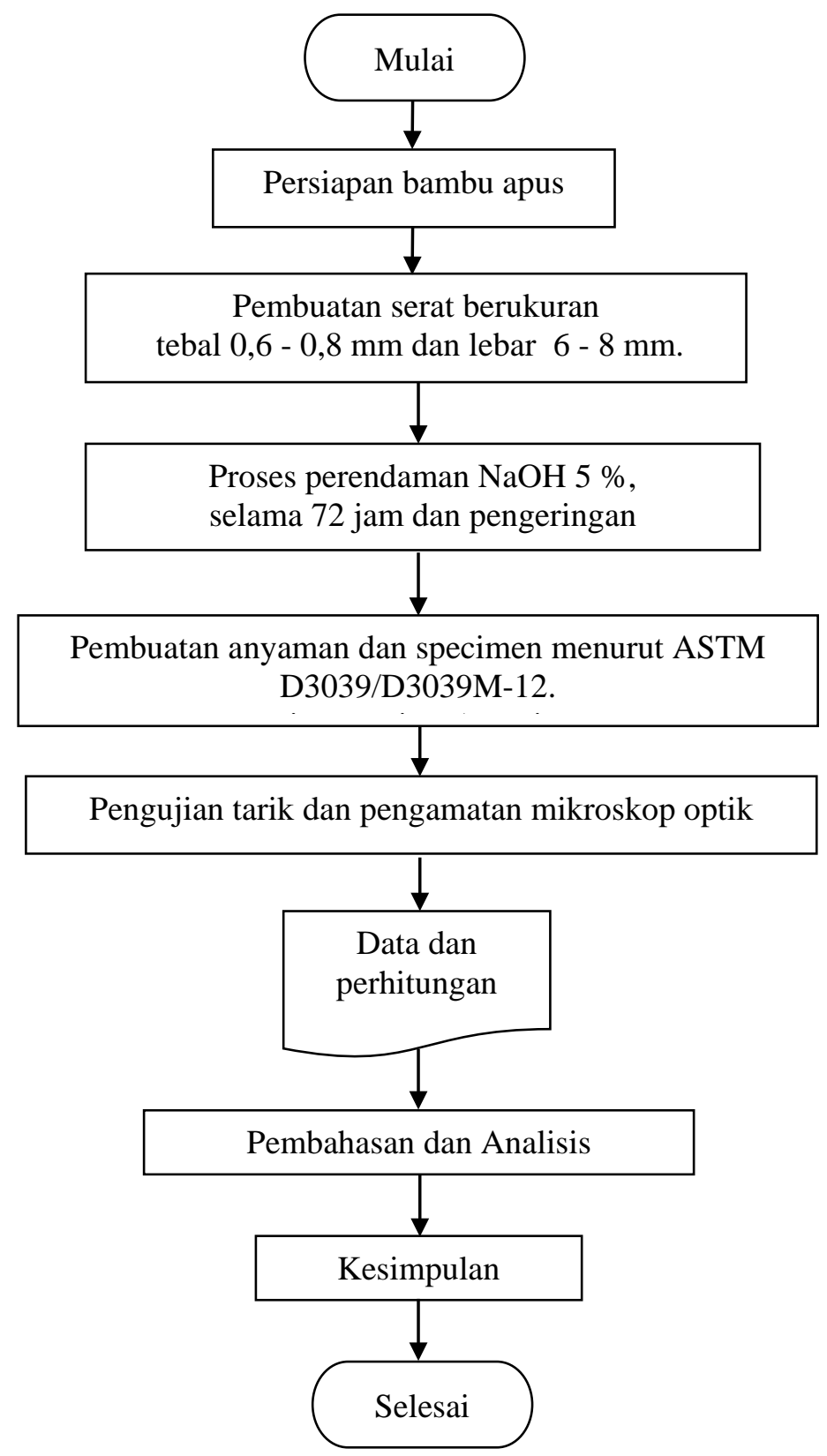

Gambar 1. Diagram alir metode penelitian

\section{Tahapan Penelitian}

\section{Tahapan bahan baku bambu}

a. Bambu diambil dari desa Pegasiran, Parung Panjang, Bogor, Jawa Barat. Jenis Bambu apus (giganchtoloa apus), berumur 3 - 4 tahun

b. Bambu dikeringkan dengan udara sekitarnya selama 2 minggu, lalu dipotong dengan pisau secara manual, hingga berbentuk serat berukuran; tebal 0,6-0,8 mm dan lebar $6-8 \mathrm{~mm}$.

\section{Proses Perlakuan Alkali}

Proses perlakuan alkali pada bambu dengan tujuan untuk memisahkan serat dengan hemicellulosa lignin, sehingga dapat meningkatkan kekasaran permukaan serat.

a. Proses perendaman dengan $\mathrm{NaOH}$ 5\%, selama 72 jam.

b. Dikeringkan pada temperatur ruang, selama 48 jam. 


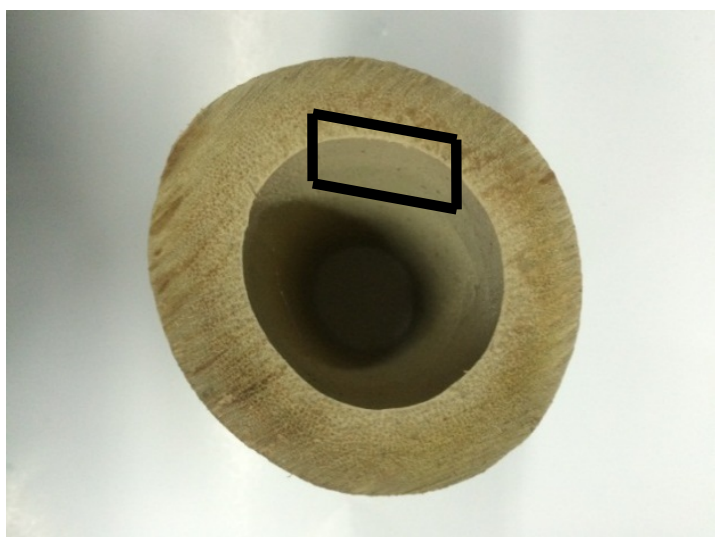

Gambar 2. Penampang bambu

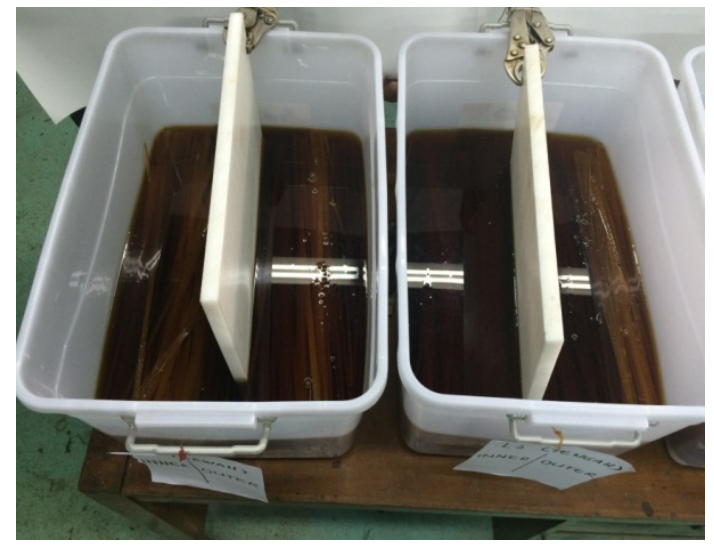

Gambar 4. Proses perendaman dengan $\mathrm{NaOH}$ $5 \%$ selama 72 jam

\section{Komposit matrik polimer.}

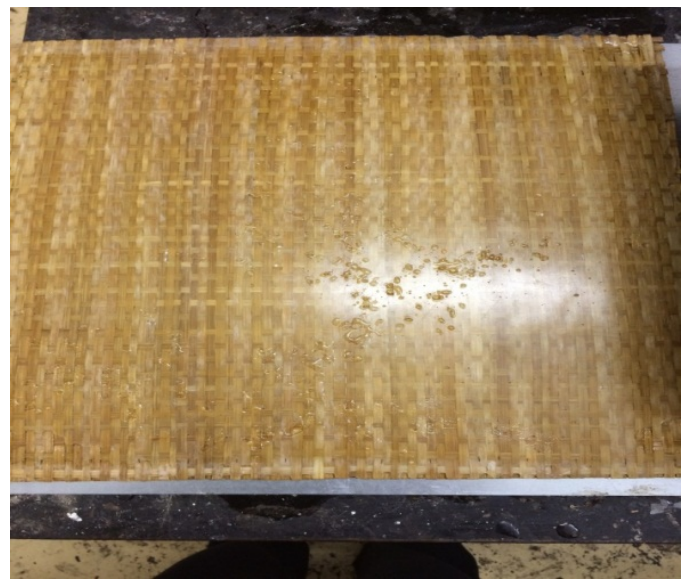

Gambar 6. Komposit anyaman twill Setelah proses manufaktur

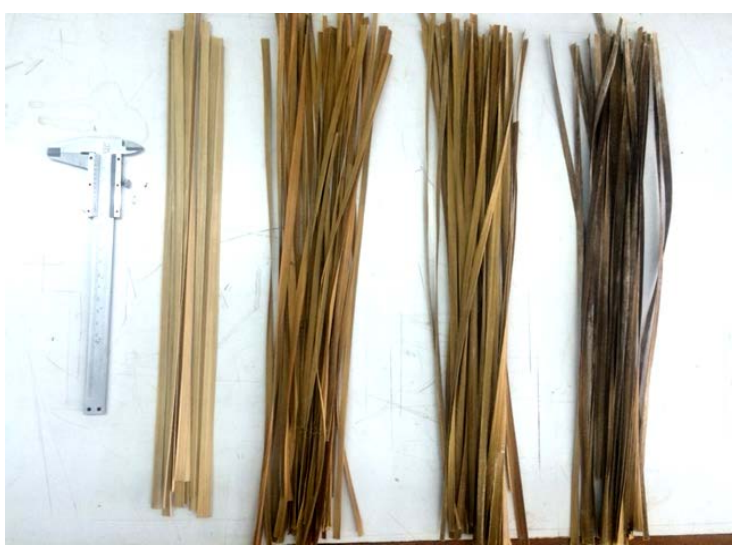

Gambar 3. Serat bambu

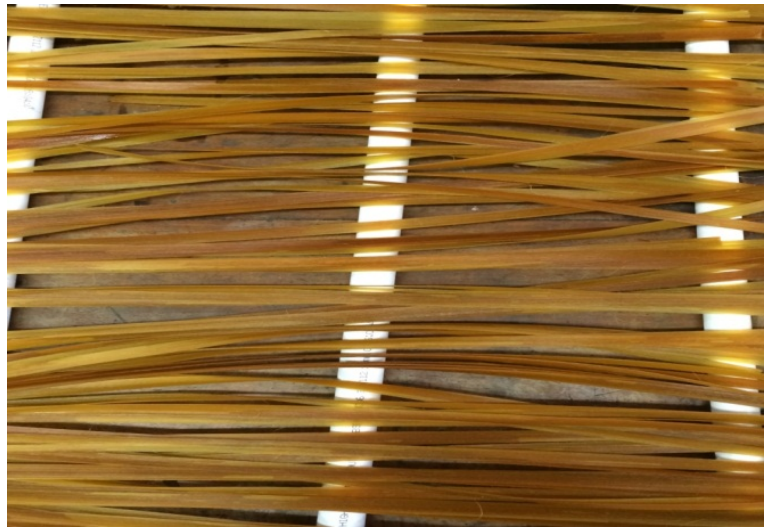

Gambar 5. Proses pengeringan serat bambu pada temperatur ruang

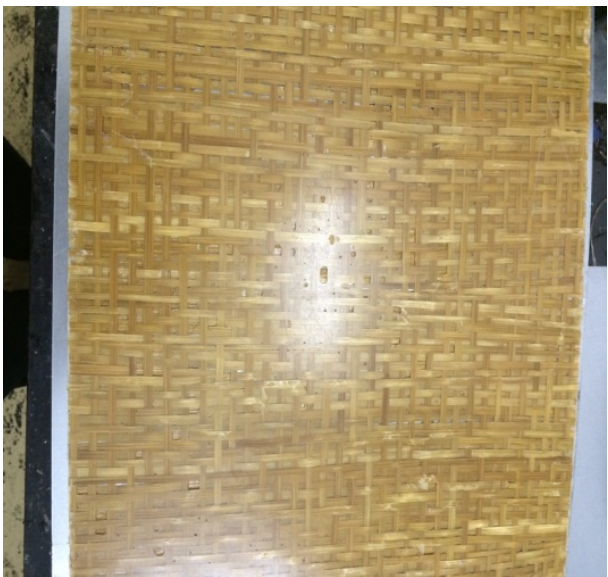

Gambar 7. Komposit anyaman plain setelah proses manufaktur

\section{Pemotongan Spesimen}

a. Sebelum melakukan pemotongan spesimen, dilakukan pengukuran di atas komposit, untuk menentukan letak pengembilan spesimen

b. Spesimen pengujian dipotong, dengan menggunakan laser cutting, dengan ukuran standard ASTM D 3039. 


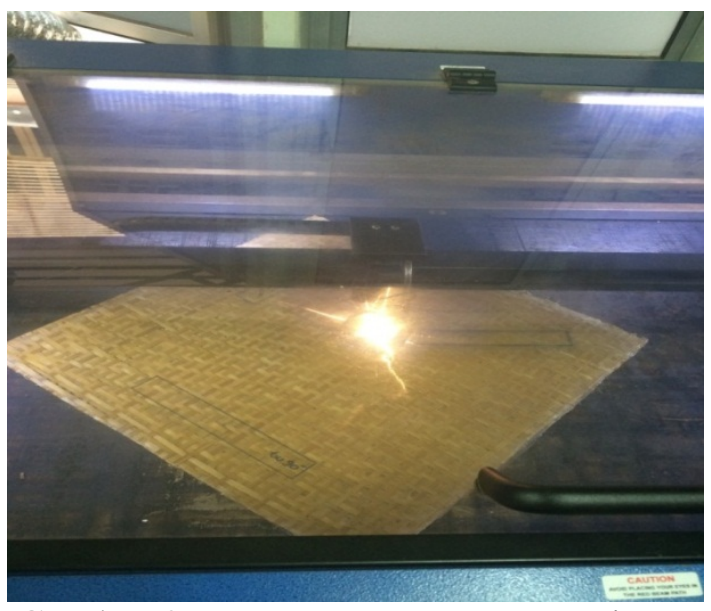

Gambar 8. Proses pemotongan spesimen dengan laser cutting

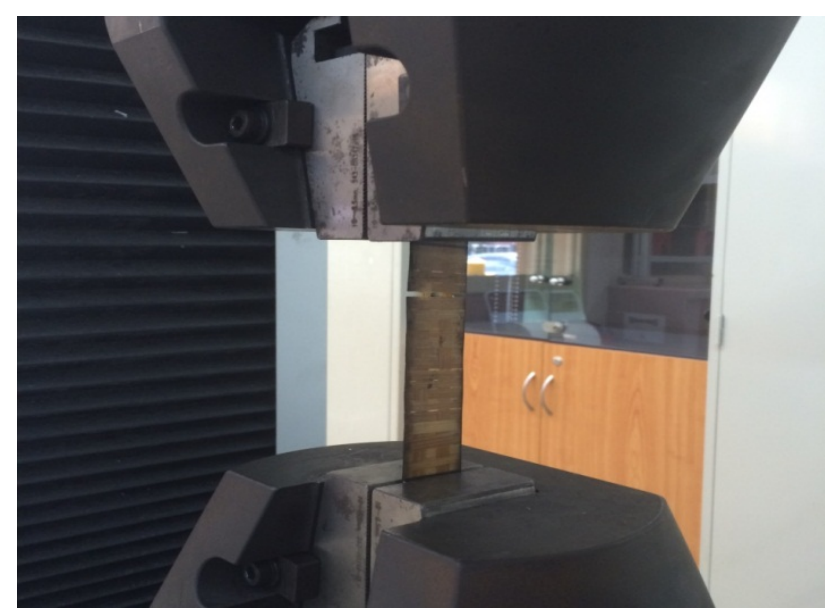

Gambar 9. Proses uji tarik komposit

\section{Proses Pengujian Tarik}

a. Pengujian tarik dilakukan dengan menggunakan universal testing machine.

b. Menggunakan load cell $5000 \mathrm{~kg}$

\section{Spesimen Hasil Uji Tarik Anyaman Plain Dan Twill Weave}

Dalam melakukan uji tarik, untuk mendapatkan data uji yang akurat, maka dilakukan pengujian sebanyak 5 spesimen.

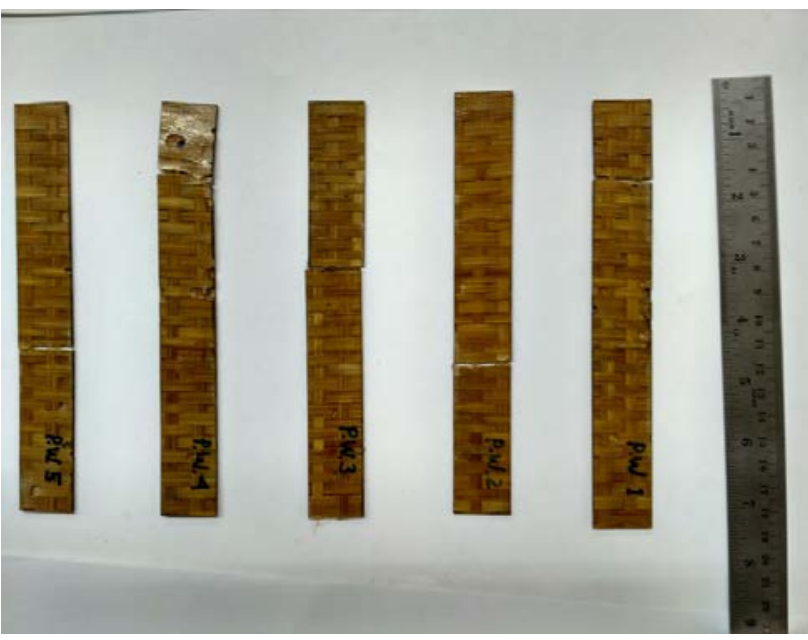

Gambar 10. Spesimen hasil uji tarik anyaman plain

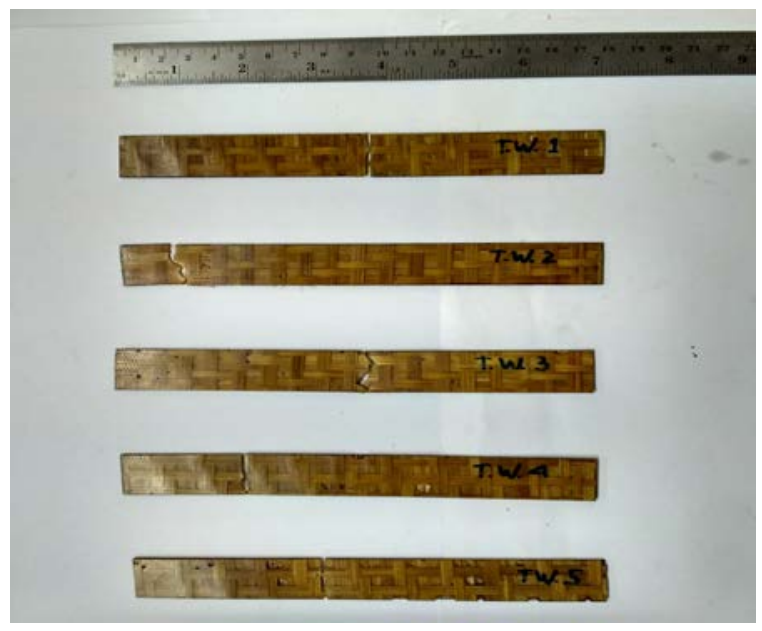

Gambar 11. Spesimen hasil uji tarik anyaman twill

\section{HASIL DAN PEMBAHASAN}

Pada Gambar 12 menunjukkan hubungan kekuatan luluh sebelum dan setelah proses alkali pada setiap jenis anyaman. Untuk jenis anyaman plain sebelum proses alkali kekuatan luluh 15,60 \pm 2,24 MPa, setelah proses alkali kekuatan luluh 18,80 \pm 2,13 MPa. Untuk jenis anyaman twill sebelum proses alkali kekuatan luluh 24,48 \pm 3,92 $\mathrm{MPa}$, setelah proses alkali kekuatan luluh 29,90 $\pm 2,27 \mathrm{MPa}$.

Pada Gambar 13, menunjukkan hubungan kekuatan tarik maksimum sebelum dan setelah proses alkali pada setiap jenis anyaman. Untuk jenis anyaman plain sebelum proses alkali kekuatan tarik maksimum 20,94 \pm 3,69 MPa, setelah proses alkali kekuatan tarik maksimum 25,53 \pm 3,94 MPa. Untuk jenis anyaman twill sebelum proses alkali kekuatan tarik maksimum 30,18 \pm 7,26 MPa, setelah proses alkali kekuatan tarik maksimum 35,15 \pm 2,81 MPa. 


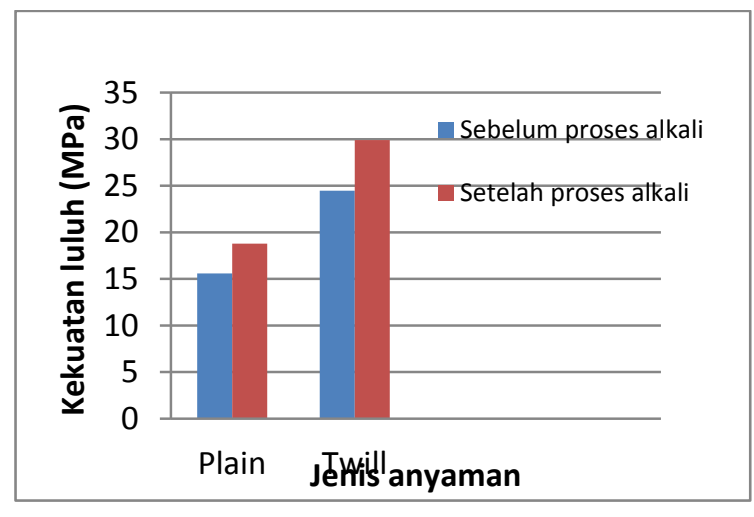

Gambar 12. Grafik hubungan kekuatan luluh dengan jenis anyaman sebelum dan setelah proses alkali

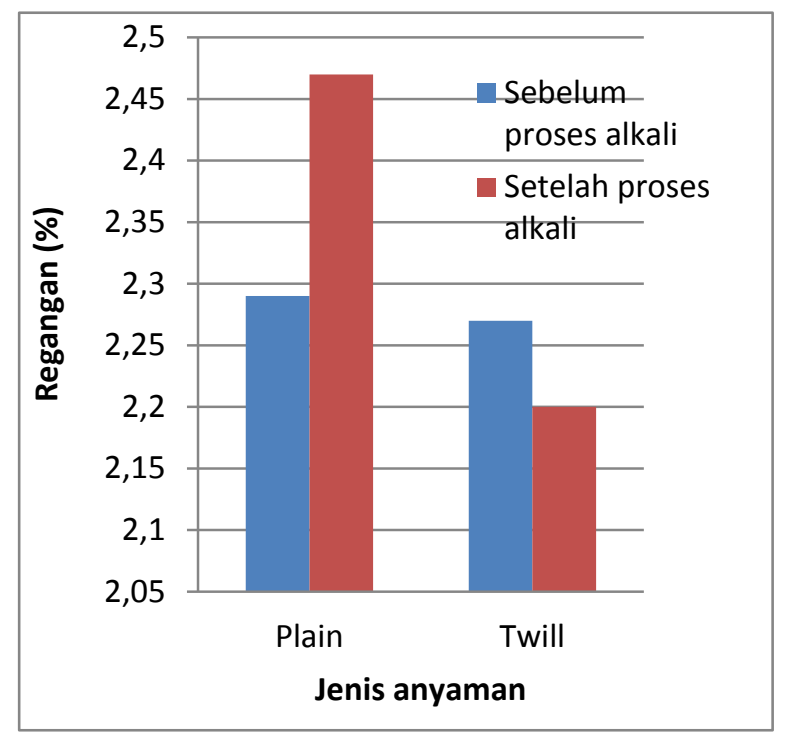

Gambar 14. Grafik hubungan regangan dengan jenis anyaman sebelum dan setelah proses alkali

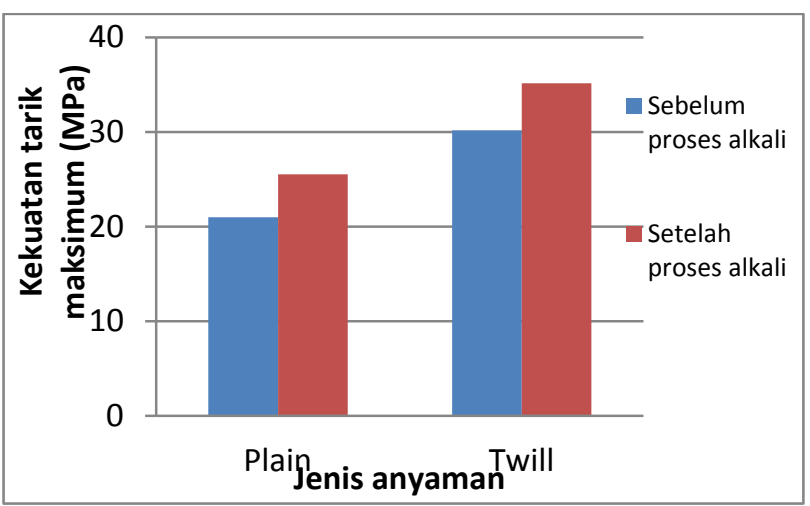

Gambar 13. Grafik hubungan kekuatan tarik dengan jenis anyaman sebelum dan sesudah proses alkali

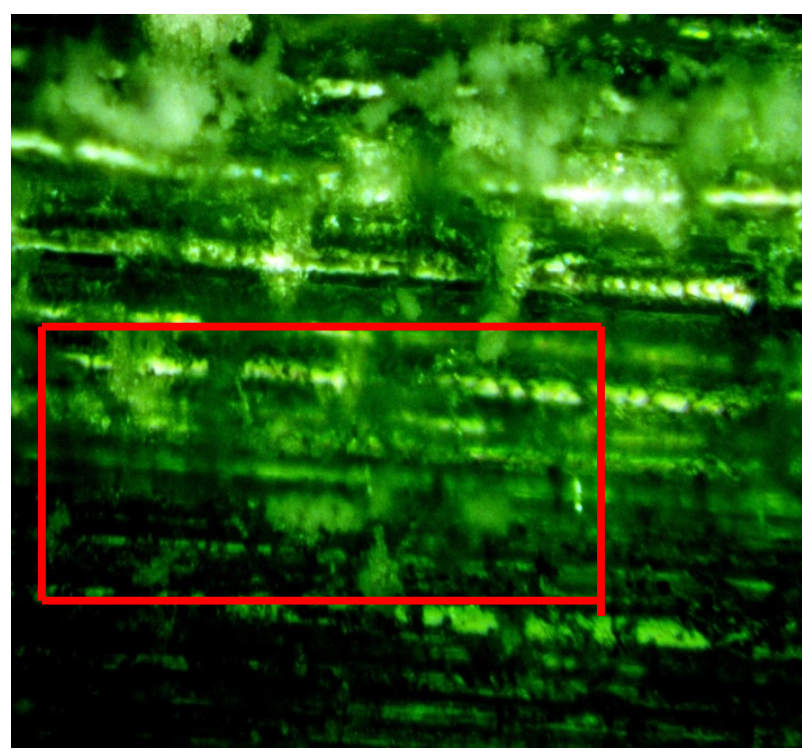

Gambar 15. Struktur serat bambu sebelum sebelum proses alkali

Pada Gambar 14, menunjukkan hubungan regangan sebelum dan setelah proses alkali pada setiap jenis anyaman. Untuk jenis anyaman plain sebelum proses alkali regangan 2,29 $\pm 0,36 \%$, setelah proses alkali regangan $2,47 \pm 0,25 \%$. Untuk jenis anyaman twill sebelum proses alkali regangan 2,27 $\pm 0,40 \%$, setelah proses alkali regangan $2,27 \pm 0,40 \%$. Pada gambar 15 , menunjukkan hasil mikroskop optik dengan pembesaran 200x, untuk pengamatan struktur serat pada bambu tanpa proses alkali, pada struktur serat terlihat adanya hemicellulosa lignin pada permukaan bambu, yang bentuknya seperti awan yang mengambang pada permukaan, yang ditandai dalam kotak merah. Pada Gambar 16, menunjukkan hasil mikroskop optik dengan pembesaran 200x, untuk pengamatan struktur serat pada bambu setelah proses alkali, pada struktur serat tidak terlihat adanya hemicellulosa lignin pada permukaan bambu, sehingga permukaannya lebih kasar dibandingkan dengan struktur serta sebelum proses alkali, yang ditandai dalam kotak merah.

Pada Gambar 17 dan Gambar 18, merupakan permukaan patah pada jenis anyaman plain weave, hasil pengamatan dengan menggunakan mikroskop optik, pembesaran 200x. Bentuk patahan berbentuk rata, ini menunjukkan material komposit dengan anyaman plain weave bersifat getas, dengan regangan bernilai 2,47\%. 


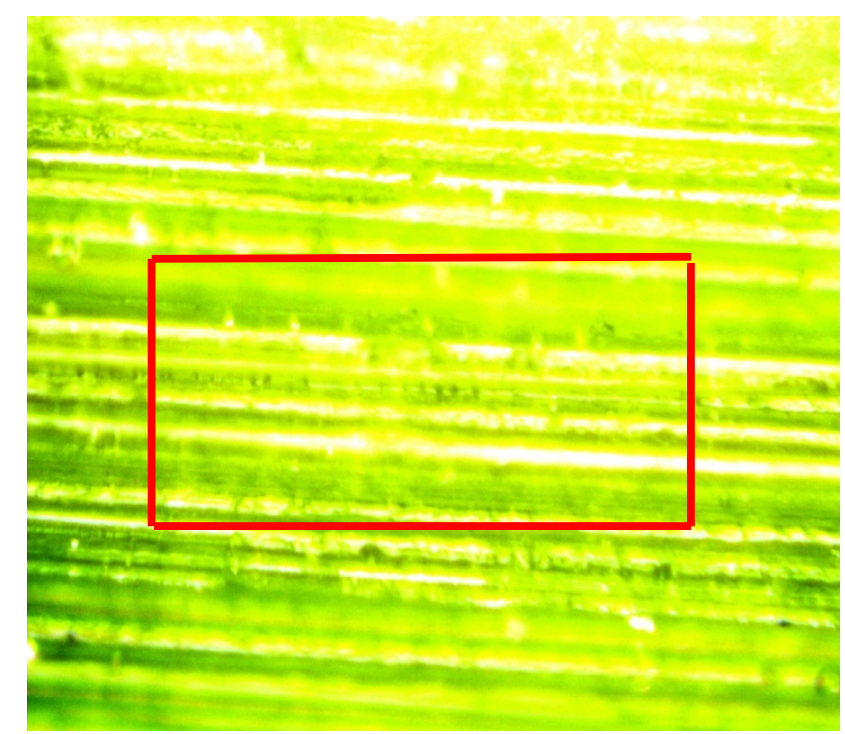

Gambar 16. Struktur serat bambu setelah proses alkali (pembesaran $200 \mathrm{x}$ )

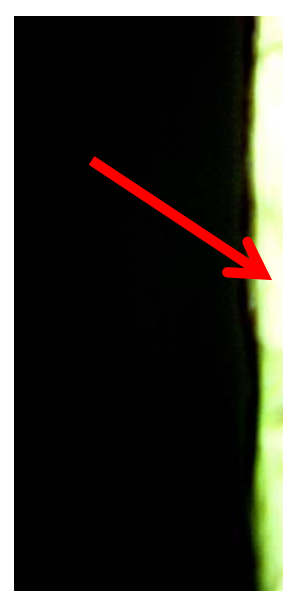

Gambar 18. Patahan posisi kedua pada plain weave (pembesaran $200 \mathrm{x}$ )

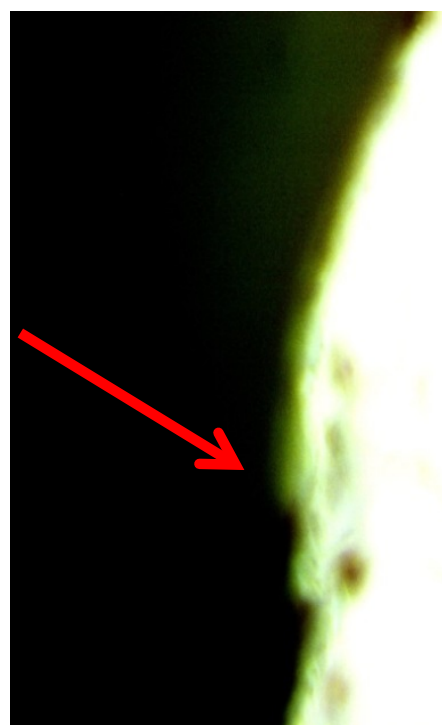

Gambar.17. Patahan posisi pertama pada plain weave (pembesaran $200 \mathrm{x}$ )
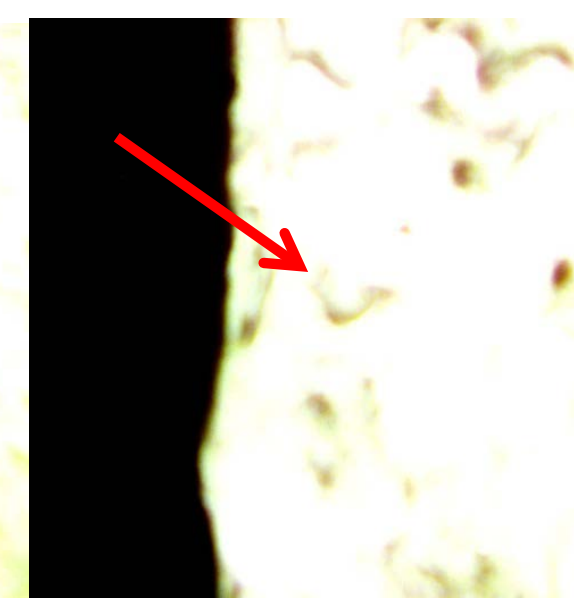

Gambar 19. Patahan posisi pertama pada twill weave (pembesaran $200 \mathrm{x}$ )

Pada Gambar 19 dan Gambar 20, merupakan permukaan patah pada jenis anyaman twill weave, hasil pengamatan dengan menggunakan mikroskop optik, pembesaran 200x. Bentuk patahan berbentuk rata, ini menunjukkan material komposit dengan anyaman twill weave bersifat getas, dengan regangan ber nilai 2,20\%.
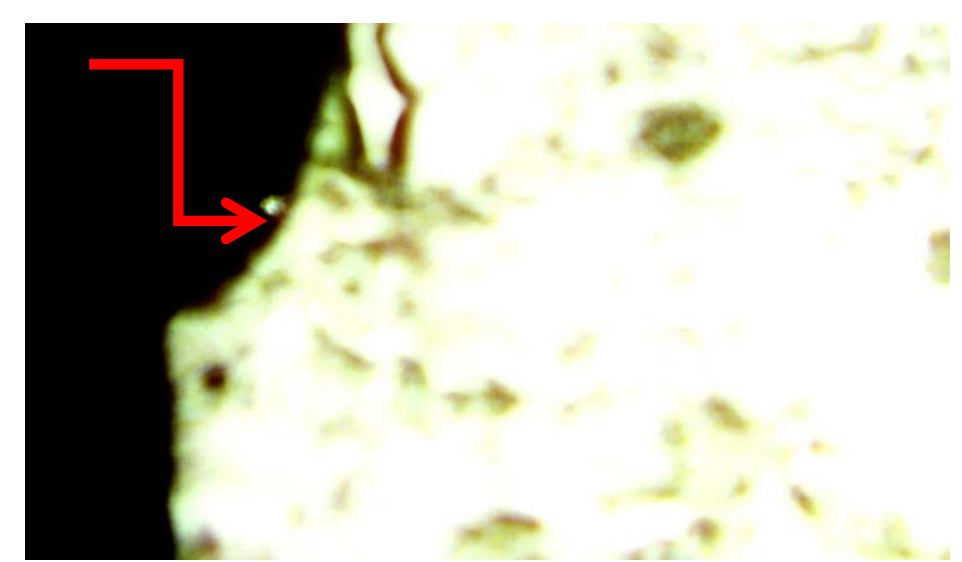

Gambar 20. Patahan pada posisi kedua pada twill weave (pembesaran $200 \mathrm{x}$ ) 


\section{SIMPULAN}

Dari data penelitian dan pembahasan, maka dapat disimpulkan sebagai berikut: 1) Untuk jenis anyaman plain sebelum proses alkali kekuatan luluh 15,60 \pm 2,24 MPa, setelah proses alkali kekuatan luluh 18,80 $\pm 2,13 \mathrm{MPa}$. 2) Untuk jenis anyaman twill sebelum proses alkali kekuatan luluh 24,48 \pm 3,92 MPa, setelah proses alkali kekuatan luluh 29,90 $\pm 2,27 \mathrm{MPa}$. 3) Untuk jenis anyaman plain sebelum proses alkali kekuatan tarik maksimum 20,94 \pm 3,69 MPa, setelah proses alkali kekuatan tarik maksimum 25,53 $\pm 3,94 \mathrm{MPa}$. 4) Untuk jenis anyaman twill sebelum proses alkali kekuatan tarik maksimum 30,18 \pm 7,26 MPa, setelah proses alkali kekuatan tarik maksimum 35,15 \pm 2,81 MPa. 5) Untuk jenis anyaman plain sebelum proses alkali regangan 2,29 $\pm 0,36 \%$, setelah proses alkali regangan 2,47 $\pm 0,25 \%$. 6) Untuk jenis anyaman twill sebelum proses alkali regangan $2,27 \pm 0,40 \%$, setelah proses alkali regangan $2,27 \pm 0,40 \%$.

\section{DAFTAR PUSTAKA}

[1]. Schwartz, Mel M., 2002, Composite Materials Handbook, Second Edition, United States of America: McGraw-Hill.

[2]. American Society for Testing and Material International, 2002, The Composite Materials Handbook, Polymers Matrix Composite, volume 3, Baltimore USA: ASTM International.

[3]. Yan Yu, Hankun Wang, Fung Lu, Genlin and Jingun Lin, 2014, Bambo Fibers for Composite Applications; a Mechanical and Morphological Investigation, Journal Materials Science, 49: 2559-2566.

[4]. A.V. Ratna Prasad, K. Mohana Rao, 2011, Mechanical Properties of Natural Fibre Reinforced - Polyester Composites: Jowar, Sisal and Bamboo, Materials and Design 32: 4658-4663.

[5]. American Society for Testing and Material International, 2008, ASTM D3039/D3039M-08 Standard Test Method for: Tensile Properties of Polymer Matrix Composite Materials, West Conshohocken USA: ASTM International.

[6]. C.S.Verma, et al, 2014, Comparative Study of Mechanical Properties of Bamboo Laminae and Their Laminate with Woods and Wood Based Composites, Composite: Part B 60: 523-530.

[7]. G. Petrone, S.Rao, et.al, 2013, Behaviour of Fibre-reinforced Honeycomb Core Under Low Velocity Impact Loading, Composite Structure 100: 356-362.

[8]. Jamasri, 2008, Prospek Pengembangan Komposit Serat Alam di Indonesia, Yogyakarta: Fakultas Teknik Universitas Gadjah Mada.

[9]. K. Murali Mohan Rao, K. Mohana Rao, 2010, Fabrication and Testing of Natural Fibre Composites; Vakka, Sisal, Bamboo and Banana, Materials and Design 31: 508 -513.

[10]. Kazuya Okubo, Toru Fuji and Yuzo Yamamoto, 2014, Development of Bamboo Based Polymer Composites and Their Mechanical Properties, Composite: Part A 35: 377 -383.

[11]. Manuhuwa, E. dan M. Loiwatu, 2007, Chemical Component and Anatomical Features of Three Species of Bamboo, Faculty of Agriculture, Pattimura University, Ambon Maluku.

[12]. Puja Hendrawan, 2005, Sifat Mekanis Panel Structural dan Kombinasi Bambu Tali, Departemen Hasil Hutan, Fakultas Kehutanan, Institut Pertanian Bogor.

[13]. M.Y.M. Zuhri, Z.W. Guan and W.J. Cantwell, 2014, The Mechanical Properties of Natural Fibre Based Honeycomb Core Materials, Composite: Part B 58: 1- 9.

[14]. Seema Jain and Rakesh Kumar, 1992, Mechanical Behavior of Bamboo and Bamboo Composite, Journal Material Science 27: 4598-4604.

[15]. Vivek Dhand A, et al, 2015, A Short Review on Basalt Fiber Reinforced Polymer Composites, Composites: Part B 73: 166-180. 